Jurnal Perpustakaan Universitas Airlangga:

Media Informasi dan Komunikasi Kepustakawanan https://e-journal.unair.ac.id/JPERPUS

\section{PADJADJARAN UNIVERSITY LIBRARY SERVICES DURING THE COVID-19 PANDEMIC}

\author{
PELAYANAN PERPUSTAKAAN UNIVERSITAS PADJADJARAN \\ SELAMA PANDEMI COVID-19
}

\section{Research Report}

Penelitian

\author{
Putri Martina Nursinta*, Sukaesih, Evi Nursanti Rukmana, Samson CMS \\ Program Studi Perpustakaan dan Sains Informasi Universitas Padjadjaran, Bandung - Indonesia
}

\section{A B S T R A C T}

Covid-19 at the beginning of 2020 caused the cessation of all activities including services in the library. This is done to avoid direct contact with users in order to prevent the spread of the Covid-19 virus. The purpose of this study was to fulfill the tasks given by the lecturers and to find out what innovations were made by the Padjadjaran University library in serving users during this Covid-19 pandemic. This study uses descriptive qualitative methods regarding concepts related to library science, as well as to analyze the practices used by libraries during the pandemic. Data were obtained through interviews conducted by researchers by sending several questions via email to the staff of the Central Library of Padjadjaran University. The data that has been obtained will be presented in descriptive form. The results showed that the importance of providing online library services by applying the concept of a digital library. The Padjadjaran University library also subscribes to several journals and ebook databases, information services related to information sources are still needed to support student and lecturer research, in this case the library can collaborate between libraries. During the pandemic, university library services are required to transform from manual services to digital services.

\footnotetext{
A B S T R A K

Covid-19 di awal tahun 2020 menyebabkan berhentinya seluruh aktivitas termasuk dengan layanan yang ada di perpustakaan. Hal tesebut dilakukan untuk menghindari kontak langsung dengan pengguna supaya dapat mencegah penyebaran virus Covid19 ini. Tujuan penelitian ini adalah untuk memenuhi tugas yang telah diberikan dosen serta untuk mengetahui inovasi apa yang dilakukan oleh perpustakaan Universitas Padjadjaran dalam melayani pengguna dalam masa pandemi Covid-19 ini. Penelitian ini menggunakan metode kualitatif deskriptif mengenai konsep-konsep yang berkaitan dengan ilmu perpustakaan, serta untuk menganalisis praktik yang digunakan perpustakaan selama pandemi. Data diperoleh melalui hasil wawancara yang telah dilaksanakan oleh peneliti dengan mengirimkan beberapa pertanyaan melalui e-mail staf perpustakaan pusat Universitas Padjadjaran. Data yang telah diperoleh akan disajikan dalam bentuk deskriptif.
}

\section{NFO ARTICLE}

Received: Nopember 2020

Accepted: August 2021

Published: Nopember 2021

Correspondence:

Putri Martina Nursinta

Email:

putri19027@mail.unpad.ac.id

\section{Keywords:}

Library, Covid-19 Pandemic, Information Communication 
Hasil penelitian menunjukkan bahwa pentingnya penyediaan layanan perpustakaan online dengan menerapkan konsep perpustakaan digital. Perpustakaan Universitas Padjadjaran juga berlangganan beberapa jurnal dan database e-book, layanan informasi yang berkaitan dengan sumber informasi tetap diperlukan untuk menunjang penelitian mahasiswa dan dosen, dalam hal ini perpustakaan dapat melakukan kerjasama antar perpustakaan. Selama pandemi, layanan perpustakaan universitas diharuskan bertransformasi dari layanan manual menjadi layanan digital.

Kata Kunci:

Perpustakaan, Pandemi

Covid-19, Komunikasi

Informasi

\section{PENDAHULUAN}

Sejak tanggal 2 Maret 2020, pemerintah Indonesia mengumumkan bahwa sudah terdapat 2 pasien positif Covid-19. Pada saat pandemi, penyebaran rantai virus Covid-19 sangat membahayakan, dikarenakan penyebarannya yang sangat cepat. Seseorang yang terjangkit virus covid-19 dengan sangat mudah bisa menularkan virus tersebut melalui droplet (percikan cairan) pada saat batuk, bersin, atau berbicara. Karena penyebarannya yang sangat cepat inilah, sehingga oleh pemerintah covid-19 ditetapkan sebagai suatu bencana darurat nasional. Pemerintah menghimbau masyarakat untuk social distancing dan physical distancing, kebijakan pemerintah lainnya yaitu dengan adanya PSBB (Pembatasan Sosial Berskala Besar) guna mengurangi rantai penyebaran. Akibat dari adanya pandemi Covid19 ini mengharuskan para pekerjauntuk bekerja dari rumah atau WFH (Work from Home), hal tersebut akhirnya mengakibatkan sistem informasi perpustakaan berjalan secara online.

Perpustakaan merupakan salah satu sarana penting untuk menunjang mahasiswa dalam kegiatan belajar. Pandemi covid-19 ini selain menghambat sistem pembelajaran, juga menghambat penelitian mahasiswa. Kebijakan pengembangan koleksi guna untuk kebutuhan penggunanya pada masa pandemi covid-19 ini, para pustakawan menambahkan berbagai referensi pembelajaran serta penambahan koleksi baru secara online, misalnya melalui sistem $e$ Book. Selain itu dalam hal layanan, lembaga bidang perpustakaan yaitu IFLA (International Federation of Library Associations and Institutions) mengemukakan bahwa untuk menghadapi pandemi covid-19 yaitu dengan membuka akses secara virtual, dan memfasilitasi akses jarak jauh mengenai publikasi akademis maupun artikel agar proses pembelajaran maupun penelitian akan terus berlanjut. Semua jenis perpustakaan telah mempromosikan layanan digital mereka misalnya, Bibliotheque nationale de France yang menyelenggarakan pameran virtual dan alat pembelajaran lainnya. (IFLA, 2020)

Saat ini, media massa mengikuti berita melalui TV, media sosial atau media onlinelainnya. Pembelajaran dilakukan secara online, maka sistem perpustakaan pun terpaksa harus ditutup. Dengan memanfaatkan teknologi informasi dan komunikasi,pengembangan koleksi perpustakaan secara online diharapkan dapat mengoptimalkanlayanan jarak jauh ini, agar sistem pembelajaran tetap berjalan sebagaimana mestinya. Para pustakawan dapat memberikan layanan berupa online melalui website resmi pada setiap kampus dengan mengembangkan perpustakaan digital sehingga akan dapat memudahkan penggunanya pada saat pandemi covid-19 ini. Melalui perpustakaan digital, perpustakaan dapat mengembangkan koleksi, meningkatkan kualitas dan mendapatkan peluang untuk mempromosikan perpustakaan dalam rangka mengembangkan eksistensinya meskipun sedang dalam kondisi pandemi covid-19. Berdasarkan penjabaran studi pendahuluan tersebut, artikel ini berfokus kepada pengembangan koleksi dan layanan perpustakaan dimasa pandemi covid-19.

Menurut teori Ranganathan mengenai lima hukum teori ilmu perpustakaan menyebutkan bahwa perpustakaan merupakan organisasi yang tumbuh (growing organism). Perpustakaan harus mulai mengubah perpustakaan fisiknya menjadi bentuk non fisik atau digital agar dapat diakses masyarakat kapanpun dan dimanapun. Perkembangan teknologi informasi memungkinkan perpustakaan untuk memanfaatkannya dengan membuat 
perpustakaan digital dalam bentuk web yang responsif. Beberapa permasalahan yang terkait dengan perpustakaan digital adalah belumadanya konsep yang jelas tentang pengembangan dan desain perpustakaan digital. Adanya permasalahan tersebut juga berpengaruh terhadap konten yang tersedia di websitetersebut. Maka komunikasi informasi sangat berperan untuk pengembangan sebuah perpustakaan digital serta untuk sarana komunikasi yang baik agar dapat digunakan secara maksimal oleh pemustaka.

Sulistyo-Basuki $(1991,51)$ mengemukakan bahwa perpustakaan perguruan tinggimerupakan perpustakaan yang bertempat di perguruan tinggi, maupun kelembagaan yang berafiliasi dengan perguruan tinggi, dengan tujuan dapat membantu perguruan tinggi mencapai tujuan yang diraihnya. Sedangkan menurut Soejono Trimo $(1992,3)$ mengemukakan bahwa perpustakaan perguruan tinggi ini merupakan sebuah lembaga yang dikelola, dikembangkan, serta menyebarkan pendapat, pola pikir dan gagasan manusia dalam bentuk buku. Perpustakaan diperuntukkan tidak hanya untuk civitas akademik yang berada di dalam universitas tersebut, melainkan juga diperuntukkan untuk individu di luar lembaga tersebut atau dapat diakses secara umum. Jadi, dapat disimpulkan bahwa fasilitas perpustakaan perguruan tinggi ini dapat secara luas digunakan oleh masyarakat umum atau civitas akademik penguruan tinggi lainnya.

Perpustakaan perguruan tinggi ini merupakan perpustakaan yang terletak di lingkungan perguruan tinggi, sekolah tinggi, akademi atau sekolah tinggi lainnya. Perguruan tinggi pasti memiliki perpustakaan yang berfungsi untuk membantu pembelajaran civitas akademika. Karena proses pendidikan tidak bisa terlepas dari kegiatanpenelitian dan inovasi ilmu pengetahuan. Sehingga perpustakaan perguruan tinggi dapat dikatakan sebagai jantungnya universitas tersebut. Perpustakaan juga memiliki tujuan yaitu untuk memenuhi pelaksanaan program perguruan tinggi sesuai dengan Tri Dharma Perguruan Tinggi yang mencakup pendidikan dan pengajaran, penelitian serta pengabdian masyarakat. Menurut Peraturan Kepala Perpustakaan Nasional Republik Indonesia
Nomor 13 Tahun 2017 tentang Standar Nasional Perpustakaan Perguruan Tinggi yaitu untuk mencapai tujuannya, perpustakaan wajib menyelenggarakan fungsi pendidikan, penelitian, informasi, hiburan, dan pelestarian. (PERPUS UNUSA, 2016)

Menurut (Sulistyo-Basuki, 1993) tujuan perpustakaan perguruan tinggi yaitu; (1) Memenuhi berbagai keperluan yang berhubungan dengan informasi, khususnya untuk para staf pengajar (dosen) maupun mahasiswa, (2) Menyediakan berbagai referensi pada semua tingkatan akademis, artinya dari mulai mahasiswa program sarjana, magister maupun doktor serta pengajar, (3) Menyediakan ruang belajar bagi penggunanya, (4) Menyediakan jasa layanan peminjaman buku, (5) Menyediakan jasa informasi aktif yangdiperuntukkan untuk civitas akademika perguruan tinggi lainnya. Berdasarkan gagasan tersebut, maka simpulan dari tujuan perpustakaan perguruan tinggi yaitu sebagai sarana pendukung dalam menyediakan berbagai referensi atau sumber-sumber informasi dalam bentuk buku, artikel maupun jurnal dan melakukan jasa layanan berupa peminjaman buku dan jasa informasi aktif. Fungsi perpustakaan perguruan tinggi menurut Noerhayati (1987) dibagi menjadi 2 fungsi, diantaranya ialah: Dari segi proses pelayanan, perpustakaan perguruan tinggi berfungsi sebagai pusat terkumpulnya berbagaiinformasi maupun referensi dan sebagai pusat penyebarluasan informasi. Dari segi programnya, perpustakaan perguruan tinggi yaitu sebagai faktor pendukung dalam program pendidikan maupun pembelajaran, program penelitian mahasiswa, dan program pengabdian pada masyarakat.

Sedangkan berdasarkan Buku Pedoman Perpustakaan Perguruan Tinggi (Depdiknas, 1994) perpustakaan perguruan tinggi memiliki fungsi, diantaranya ialah: (1) Fungsi Edukasi, Perpustakaan merupakan sumber proses pembelajaran para civitas akademika, maka koleksi yang disediakan oleh perpustakaan yaitu berupa penunjang tujuan pembelajaran, pengklasifikasian bahan pembelajaran pada setiap program studi, koleksi mengenai strategi belajar mengajar dan materi pendukung pelaksanaan evaluasi pembelajaran, (2) Fungsi 
Informasi, Perpustakaan sebagai sumber informasi, yang dapatdiakses secara mudah oleh penggunanya, (3) Fungsi Riset, Perpustakaan menyediakan bahan-bahan penelitian dan berbagai pengkajian ilmu pengetahuan. Pengembangan koleksi sebagai pendukung penelitian, serta hasil-hasil karya penelitian yang dapat diterapkan untuk kepentingan civitas akademika diberbagai bidang pendidikan, (4) Fungsi Rekreasi, Perpustakaan menyediakan berbagai koleksi rekreatif yang bermakna, guna membangun dan mengembangkan berpikir secara kreatif, meningkatkan minat dan daya inovasi penggunanya, (5) Fungsi Publikasi, Perpustakaan juga melayani dan membantu proses publikasi karya yang dihasilkan oleh civitas akademika, (6) Fungsi Deposit, Perpustakaan juga menjadi pusat deposit (simpanan) untuk berbagai karya serta pengetahuan yang dihasilkan civitas akademika di perguruan tingginya, (7) Fungsi Interpretasi, bahwa seharusnya perpustakaan sudah melakukan berbagai kajian dan memberikan nilai tambah terhadap informasi serta referensi yang dimilikinya guna membantu serta mempermudah penggunanya. Maka dapat disimpulkan bahwa fungsi perpustakaan perguruan tinggi ini dapat mendukung program pendidikan, serta penelitian. Perpustakaan perguruan tinggi juga sudah menjalankan fungsinya yaitufungsi edukasi, fungsi informasi, fungsi riset, fungsi rekreasi, fungsi publikasi, fungsi deposit, serta fungsi interpretasi.

Perpustakaan digital berawal dari Negara Amerika Serikat yang diterjemahkan dari bahasa Inggris yaitu "digital library". Masyarakat mengenal perpustakaan digital sebagai perpustakaan online. Dengan pesatnya perkembangan teknologi, perpustakaan digital ini pun berkembang. Definisi perpustakaan digital menurut IFLA (The International Federation of Library Associations and Intitutions) (2018), "a digital library is an online collection of digital objects, of assured quality, that are created or collected and managed according to internationally accepted principles for collection development and made accessible in a coherent and sustainable manner, supported by services necessary to allow users to retrieve and exploit the resources." Artinya perpustakaan digital adalah perpustakaan benda-benda digital berkualitas online yang dikembangkan dan dikelola secara internasional. Selain itu, pengguna dapat mengakses koleksi kapan pun dan di mana pun ketika membutuhkan informasi.

Perpustakaan digital merupakan perpustakaan yang inovatif karena menggunakan teknologi informasi yang sudah mulai berkembang. Perpustakaan digital adalah perpustakaan yang berusaha melestarikan sumber daya informasi. Oleh karena itu, keberadaan perpustakaan digital akan semakin memudahkan masyarakat untuk terus mengakses bahan pustaka dengan memanfaatkan teknologi informasi yang ada. Rowlanddan Bawden percaya bahwa perpustakaan digital adalah perpustakaan tradisional yang sedang dikembangkan. Ada beberapa penyebutan tentang perpustakaan digital yaitu perpustakaan elektronik, perpustakaan hibrid, perpustakaan digital dan perpustakaan virtual, yang membedakannya terletak pada letak dan bentuknya. Perpustakaan digital memiliki beberapa keunggulan yaitu: (1) Hemat tempat. Perpustakaan digital tidak membutuhkan ruangan yang luas, karena perpustakaan digital merupakan koleksi virtual

(2) Multi akses. Perpustakaan digital dapat diakses secara bersamaan dari mana saja,

Perpustakaan digital tidak terbatas ruang dan waktu, serta perpustakaan digital dapat diakses bila layanan tidak dibatasi jarak dan waktu. (4) Multimedia dapat digunakan. Koleksi digital bisa berupa suara, gambar, film, video, dan lain-lain. (5) Harganya murah. Saat membuat e-book di perpustakaan digital, harganya sangat mahal. Namun, e-book juga bisa disalin, sehingga $e$ document dianggap lebih murah.

Layanan perpustakaan merupakan layanan yang diberikan oleh pustakawan kepada pemustaka yang datang ke perpustakaan, untuk pemberian koleksi bahan pustakayang mencakup penyediaan berbagai macam bentuk bahan pustaka yang dibutuhkan olehpemustaka, baik di lingkungan perpustakaan ataupun di luar lingkungan perpustakaan dan penyediaan sarana penelusuran yang dapat merujuk pada bahan yang sedang dicari atau dibutuhkan oleh pemustaka. Tujuan dari layanan perpustakaan sendiri adalah untuk membantu memenuhi 
kebutuhan pemustaka secara tepat dengan cara menyediakan informasi yang dibutuhkannya. Tujuan terbentuknya sebuah layanan di perpustakaan adalah untuk memaksimalkan bahan pustaka yang dimiliki sehingga dapat dimanfaatkan secara maksimal oleh pemustaka. (Istiana, 2014)

\section{METODE PENELITIAN}

Metode yang digunakan dalam penelitian ini adalah metode kualitatif. Penelitian kualitatif mengacu pada penelitian yang menghasilkan dan mengolah data deskriptif, seperti catatan wawancara, catatan lapangan, gambar, foto, video, dan lain-lain. (K.E, 1998) Alasan penelitian kualitatif adalah karena tujuan utama penelitian adalah untuk mempelajari atau memeriksa objek dalam lingkungan ilmiah tanpa operasi apapun. Hasil yang diharapkan tidak didasarkan pada sarana kuantitatif, dan itu didasarkan pada makna ataukualitas substansi. Fenomena yang diamati. Metode penelitian ini adalah studi kasus dimana peneliti secara cermat mempelajari suatu program, peristiwa, aktivitas, proses atau sekelompok individu. (Creswell, 2012) Kasuskasus dalam pendekatan ini dibatasi oleh waktu dan aktivitas, dan peneliti mengumpulkan informasi secara lengkap dengan menggunakan berbagai prosedur pengumpulan data berdasarkan waktu yang telah ditentukan. Metode penelitian kualitatif ini merupakan salah satu metode penelitian yangsemakin berkembang dan banyak diimplementasikan dalam berbagai bidang keilmuan, terutama dalam bidang-bidang ilmu sosial humaniora, budaya, psikologi, komunikasi, dan pendidikan. Peneliti bermaksud memperoleh data mengenai inovasi Perpustakaan Universitas Padjadjaran dalam melayani pengguna dalam masa pandemi Covid-19. Data diperoleh melalui wawancara kepada beberapa staf perpustakaan pusat Universitas Padjadjaran. Wawancara dilaksanakan pada hari Rabu, 18 November 2020 dengan cara mengirimkan beberapa pertanyaan melalui e-mail. Wawancara adalah dialog, tanya jawabyang bertujuan untuk mencapai tujuan tertentu. Tujuan dari wawancara ini adalah untuk memperoleh pengetahuan tentang makna subjektif, tema tersebut adalah pemahaman pribadi dari subjek yang diteliti (K.E,
1998). Data yang sudah ada akan diolah dan dipaparkan dalam bentuk deskrtiptif. Penelitian ini termasuk dalam penelitian sosial yang menggunakan teknologi informasi berupa pelayanan dengan menggunakan internet.

\section{HASIL DAN PEMBAHASAN}

Di era digital, perpustakaan perlu menyesuaikan diri dengan tren perkembangan teknologi dan menyesuaikan dengan kebutuhan dan lingkungan perpustakaan. Seiring waktu, perpustakaan akan terus menjadi lebih kompleks dan lebih besar. Dari luar(misalnya, gedung) atau dalam (misalnya, pustakawan dan koleksinya). Pesatnya sebuah perkembangan dan perubahan teknologi membuat tuntutan masyarakat terhadap informasi menjadi semakin meningkat, sehingga mau tidak mau perpustakaan harus membuat perpustakaan yang dapat mengimbangi dengan perkembangan zaman yaitu membuat perpustakaan digital. Perpustakaan digital adalah perpustakaan tanpa perpustakaan fisik, tetapi koleksi yang dikumpulkan bersifat virtual. Tidak seperti perpustakaan hibrida, perpustakaan hibrida memiliki keduanya. Perpustakaan hibrida adalah perpustakaan tradisional yang dikembangkan menggunakan jaringan komputer. Koleksi perpustakaan campuran ada dua jenis, yaitu koleksi digital dan koleksi fisik. Perpustakaannya dapat ditemukan di dalam dan luar negeri. Hal ini dikarenakan masyarakat menginginkan akses yang mudah dan efisien terhadap sumber informasi. Namun, saat ini diyakini bahwa rujukan kedua perpustakaan tersebut sama yaitu perpustakaan digital / digital library.

Dengan pesatnya sebuah teknologi membuat perpustakaan dan pustakawan bisa memberikan layanan berupa layanan online. Dengan adanya layanan online ini akan mempermudah pengguna dalam meminjam dan mengembalikan buku dalam bentuk $e$ - book. Selain itu, perpustakaan juga memberikan layanan pertanyaan kepada perpustakaan untuk menggantikan pustakawan di perpustakaan offline. Perpustakaan juga menyediakan layanan baru seperti menonton film, game, serta layanan 
lain yang berguna dan menarik bagi pengguna dalam menggunakan perpustakaan sebagai sarana hiburan.

Kebanyakan perpustakaan perguruan tinggi sudah mulai mengembangkan perpustakaan digital dengan menggunakan bantuan perpustakaan dan situs web lainnya atau jejaring sosial yang dapat diakses melalui internet. Setiap pusat informasi atau perpustakaan pasti memiliki cara tersendiri untuk mempromosikan perpustakaannya kepada khalayak luas supaya tidak kehilangan ruang hidupnya. Selain itu, perpustakaan digital memiliki database tersendiri yang berfungsi untuk menyimpan dan mengumpulkan sumber informasi yang dimiliki oleh perpustakaan tersebut. Perpustakaan tidak hanya menyediakan sumber informasi, tetapi juga berperan serta dalam memandu pengguna. Menurut Putu Laxman Pendit (2008) dalam makalahnya yang berjudul "Perpustakaan Digital Pendidikan Tinggi: Tantangan Peningkatan Kualitas Layanan", perpustakaan harus menyediakan prosedur yang tertib untuk membantu pembaca yang hanya dapat menggunakan koleksi perpustakaan menjadi aktif. Pembaca yang mahir. Literasi informasi memiliki kemampuan untuk merumuskan strategi pencarian informasi yang sesuai dengan kebutuhan yang ada dibidangnya. Dengan menggunakan perpustakaan digital dapat memenuhi syarat-syarat yang telah dijelaskan sebelumnya karena perpustakaan dapat memberikan arahan serta petunjuk informasi mengenai layanan lain yang telah disediakan oleh perpustakaan tersebut. Sebagai organisasi yang bergerak dalam bidang pekerjaan informasi, sudah pasti perpustakaan perlu melakukan komunikasi untuk mencapai tujuan yang akan didirikan oleh perpustakaan tersebut yaitu dengan cara memenuhi kebutuhan informasi masyarakat. Komunikasi adalah syarat terpenting yang dapat mempengaruhi kebelangsungannya sebuah pusat informasi atau perpustakaan. Tanpa adanya sebuah komunikasi, proses penyebaran ilmu pengetahuan akan menjadi sulit dan tidak akan tersalurkan. Proses penyampaian ini merupakan interaksi secara langsung ataupun secara tidak langsung antara pustakawan dengan pengguna yang menjadi sebuah contoh nyata dari kegiatan komunikasi di perpustakaan.

Proses komunikasi di perpustakaan dapat dijelaskan dengan menerapkan paradigma Lasswell, yaitu cara terbaik untuk menjelaskan kegiatan informasi perpustakaan dalam paradigma ini adalah menjawab 5 (lima) pertanyaan, yaitu: who, says what, in which channel, to whom, with what effect. (Daryono, 2018) Kalau di perpustakaan, paradigmanya bisa dipahami dari siapa atau pemberi pesan, yaitu lembaga perpustakaan, hingga penerima pesan, yaitu pusatnya. Kemudian, proses komunikasi di perpustakaan (yaitu pustakawan) berperan sebagai penyebar informasi dalam bentuk informasi yang dibutuhkan. Saat akan menyebarluaskan sebuah informasi, pustakawan akan menggunakan bahan pustaka yang sudah ada berupa koleksi cetak dan non cetak atau elektronik, pustakawan juga akan memberikan informasi lanjutan kepada pengguna yang membutuhkannya. Tahap terakhir yaitu dampak atau efek yang bisa mempengaruhi perpustakaan serta pengguna dalam menggunakan bahan pustaka secara efektif dan efisien. Selain melalui komunikasi dan interaksi, perpustakaan juga menyediakan self assessment yang berfungsi untuk mengembangkan dan mengoptimalkan layanan perpustakaan yang sudah ada, sehingga proses komunikasi akan menjadi lebih baik. Pengguna perpustakaan akan selalu menanti mengenai informasi apalagi yang akan diberikan oleh pusat informasi kepada pengunjung, serta apakah bisa dijadikan sebagai bahan pendukung penelitian atau tugas-tugas mengenai perkuliahan dan informasi akademik lainnya. Proses komunikasi secara tidak langsung dapat diselesaikan dengan cara mengakses perpustakaan digital yang sudah tersedia. Interaksi yang dilakukan secara langsung dapat dilakukan dengan cara mengunjungi perpustakaan tersebut, sedangkan interaksi secara tidak langsung dapat dilakukan secara online atau dapat melalui situs web, pesan singkat, pesan suara, ataupun melalui e-mail. (Daryono, 2018)

Proses komunikasi tidak langsung dapat diselesaikan melalui perpustakaan digital. Ini adalah peran yang dibutuhkan untuk bertukar informasi. Pendirian perpustakaan digital 
bertujuan untuk memberikan kemudahan akses kepada pengguna, sehingga proses pencarian informasi menjadi lebih efektif. Selain itu, perpustakaan digitaldapat digunakan juga sebagai media promosi perpustakaan tersebut, ini juga tentunya berlaku untuk semua perpustakaan digital yang ada di perguruan tinggi, yang nantinya dapat dimanfaatkan sebagai sarana mempromosikan perpustakaan dan institusi. Maka dari itu, komunikasi informasi merupakan peran terpenting untuk meningkatkan layanan online perpustakaan digital. Melalui pertukaran informasi maka kualitas konten informasi akan semakin baik dan tampilan layanan juga akan semakin menarik.

Kini seluruh dunia sedang mengalami wabah virus Covid-19 yang awal mulanyaberasal dari kota Wuhan, China. Dengan adanya wabah ini, pemerintah menghimbau kepada masyarakat termasuk kepada pekerja dan kepada pelajar untuk melakukan aktivitasnya hanya di dalam rumah saja dan tidak meninggalkan rumah untuk mencegah penularan dan penyebarluasan virus mematikan ini. Adanya wabah ini juga memunculkan berbagai macam tanda pagar (tagar) atau hastag seperti \#WorkFromHome atau biasa disebut dengan WFH, yaitu ajakan bagi para pekerja dan pelajar untuk melakukan segala aktivitasnya di rumah saja. Melalui himbauan tersebut juga mulai memunculkan lebih banyak tanda pagar (tagar) baru yaitu \#StayAtHome dan \#SocialDistancing. Adanya virus ini telah mempengaruhi banyak hal, salah satu dampak yang terkena adalah perpustakaan. Perpustakaan tidak bisa memberikan pelayanan secara langsung, sehingga diubah sistemnya menjadi perpustakaan digital yang bisa diakses melalui web perpustakaan tersebut, sehingga pengguna masih bisa mengakses dan menggunakan layanan perpustakaan untuk memenuhi kebutuhan informasi sesuai dengan kebutuhannya, seperti penelitian atau tugas universitas. Saat ini masih banyak mahasiswa yang membutuhkan bantuan perpustakaan untuk mengakses dan memperoleh informasi dari bahan pustaka atau sumber informasi lain untuk memenuhi kebutuhannya. Perpustakaan perguruan tinggi dapat melakukan evaluasi saat menggunakan layanan digital serta memanfaatkannya sebagai peluang untuk memberikan layanan walau sedang terjadi pandemi Covid-19. Pada saat ini perpustakaan benar-benar sangat dibutuhkan karena banyak mahasiswa yang membutuhkan perpustakaan untuk mencari informasi, sehingga dengan menggunakan perpustakaan digital, pengguna akan menjadi mudah dalam mengakses informasi. Peningkatan kualitas perpustakaan digital dengan cara membangun situs web yang dirancang dengan sedemikian rupa juga akan sangat mempermudah pengguna dalam mengakses informasi. Inovasi semacam ini akan sangat mempermudah perpustakaan untuk mencapai tujuan yang diinginkan.

Ketika pandemi ini terjadi, perpustakaan fisik akan ditutup dan dipindahkan ke perpustakaan digital. Di dalam dan luar negeri, penerapan konsep perpustakaan digital universitas dapat memanfaatkan keterampilan pertukaran informasinya secara maksimal untuk mengembangkan inovasi ini. Misalnya, pembaruan kasus Covid-19 (seperti jumlah kematian dan infeksi) menyediakan video yang dapat diputar melalui tautan YouTube atau berita online. Video terjamin kredibilitasnya, seperti pencegahan, dan social distancing itu penting. Informasi tersebut dapat menambah pengetahuan pengguna, sehingga perpustakaan harus secara aktif melakukan inovasi tersebut. Selain informasi umum, perpustakaan juga bisa menyelenggarakan riset atau riset ilmiah terkait Covid-19.Banyak perpustakaan di luar negeri telah melakukan inovasi ini. Namun, belum banyak perpustakaan di Indonesia yang dapat memanfaatkan perpustakaan digitalnya secara maksimal untuk melakukan inovasi ini. Beberapa perpustakaan sudah menyediakan informasi penting ini, seperti perpustakaan Poltekkes yang tersedia melalui website http://library.poltekkessmg.ac.id/Covid-19/public/ yang menyediakan update kasus Covid-19. Memberikan pengetahuan kesehatan dan mendapatkan data real-time melalui https://Api.kawalcorona.com.

Proses kedua yang bisa dilakukan oleh perpustakaan perguruan tinggi disaat pandemi adalah memperluas kerja sama dengan perpustakaan lain. Kerja sama antar perpustakaan dapat melakukan melalui kegiatan atau berbagi sumber daya sertamemanfaatkan sumber daya 
perpustakaan yang ada. Sumber daya yang dilakukan bisa dalam bentuk informasi, koleksi ataupun personal perpustakaan. Jika perpustakaan akanmelakukan kegiatan kolaborasi tersebut, maka perpustakaan dapat menjalankan beberapa syarat diantaranya yaitu: memberikan layanan perpustakaan kepada perpustakaan lain, memberikan pelatihankepada staf perpustakaan lainnya, serta berbagi koleksi buku antara perpustakaan yang satu dengan perpustakaan yang lainnya. Kegiatan kerja sama ini telah banyak dilakukan oleh perpustakaan besar yang terletak di negara-negara maju. Maka sebaiknya perpustakaan yang ada di Indonesia juga harus bisa mengikuti langkah yang diambilnya supaya pengguna bisa lebih mudah untuk mendapatkan koleksi yang diinginkannya. Kegiatan yang dilakukan memungkinkan perpustakaan saling melengkapi kekurangan yang ada.

Menurut Posner (2017) dalam artikelnya yang berjudul "Library Information Sharing: Best Practices and Trends, Challenges and Prospects", melalui resource sharing, perpustakaan menyediakan bahan pustaka yang sulit ditemukan. Setiap perpustakaan bisa saling memuaskan kekurangan satu sama lain. Berbagi sumber daya dapat dilakukan dengan membuat database yang berisi koleksi digital. Dengan sistem ini, pengguna dapat dengan mudah mengakses dan mencari kebutuhan informasi dengan mencari koleksi digital yang ada. Perpustakaan kolaboratif dapat menyiapkan layanan yang disebut "koleksi bersama" di situs web perpustakaan, dan setiap pengguna perpustakaan dapat meminjam koleksi perpustakaan lain melalui situs web ini.

Akibat pandemi Covid-19, banyak orang bekerja dari rumah. Awalnya mereka masih menyukainya, akan tetapi lama-lama mereka juga merasa bosan. Untuk mengatasi rasa bosan, mereka biasanya mengisi waktu luang dengan membaca buku atau menonton film setelah menyelesaikan tugasnya sebagai pekerja atau pelajar. Dalam hal ini perpustakaan dapat memberikan layanan terkini sesuai dengan kebutuhan masyarakat untuk mengisi waktu luang dan mengembangkan inovasi. Layanan koleksi dalam bentuk bacaan digital sangatpenting bagi pengguna untuk memberikan layanan informasi (Suharso, 2019). Kebutuhanakan bacaan digital pada saat pandemi akan memudahkan pembaca untuk membaca tanpaharus meminta buku untuk dikirim ke perpustakaan. Misalnya perpustakaan dapat memberikan layanan pengiriman buku dan pemutaran film perpustakaan yang disediakanoleh perpustakaan Bina Nusantara melalui website http://library.binus.ac.id/.

Layanan pengiriman buku adalah layanan yang diberikan kepada pengguna dengan pengiriman ekspres atau dengan bantuan perpustakaan keliling. Dengan menerapkan regulasi tertentu sesuai regulasi masing-masing perpustakaan, perpustakaan lain dapat mengimplementasikan layanan ini. Misalnya dalam proses pengiriman, pengguna perlu meminjam hingga 3 buku, dan area pengiriman hanya dalam kota. Proses sirkulasi harus dilanjutkan. Selama proses pengembalian, buku akan diambil oleh perpustakaan dalam waktu seminggu. Tersedia juga layanan pemutaran film perpustakaan, termasuk pemutaran film Indonesia dan asing. Bagi pengguna, menggunakan layanan ini sangat menarik. Perpustakaan dapat memberikan suara melalui perpustakaan Instagram untuk memilih film mana yang akan ditayangkan di situs web perpustakaan pada waktu tertentu. Siaran tersebut dilakukan sesuai dengan jadwal yang telah ditetapkan oleh perpustakaan.

Dalam pandemi ini, perpustakaan dalam dan luar negeri telah mengubah aktivitas perpustakaannya menjadi format online / digital sehingga pengguna perpustakaan dapat mengaksesnya kapan pun dan di mana pun. Perpustakaan harus mengambil tindakan cepat dan tepat untuk beradaptasi dengan situasi di masyarakat. Setiap perpustakaan dapat memperluas cakupan pengaruh perpustakaan dan memperluas eksistensi perpustakaan di masyarakat dengan mengembangkan inovasi yang diimplementasikan atau membentuk inovasi baru, sehingga mampu menangkap peluang dalam setiap situasi yang ada. Semakin inovatif pustakawannya, semakin besar citra perpustakaannya. Hal ini sesuai dengan pandangan Haryanto (2019) bahwa pustakawan harus mengambil tindakan apapun termasuk 
inovasi terbaru untuk meningkatkan kepuasan pengguna, sehingga pengguna dapat menikmati penggunaan perpustakaan digital.

Berdasarkan hasil wawancara yang telah saya lakukan menurut ibu Sri Rakhmiyati, S.Sos., M.I.Kom selaku Koordinator Unit Perpustakaan Pusat-Pusat Pengelolaan Pengetahuan, Direktorat Pendidikan dan Internasionalisasi Universitas Padjadjaran serta beberapa staf lainnya adalah selama masa pandemi Covid-19 ini Pimpinan Pusat Pengelolaan Pengetahuan dan Perpustakaan Pusat belum mengijinkan mahasiswa dan pengguna lainnya untuk beraktifitas di lingkungan gedung Grha Kandaga, termasuk menggunakan layanan dan fasilitas Perpustakaan Pusat. Kecuali untuk layanan yang bersifat administrasi seperti pembuatan surat bebas perpustakaan, atau penyerahan tesis dan disertasi, tapi sebisa mungkin mahasiswa yang akan membuat surat-surat tersebut dilakukan secara online atau melalui e-mail ke perpustakaan@unpad.ac.id. Sehingga menghindari kontak langsung, jumlah pengunjung selama pandemi ini secara fisik dikatakan tidak ada, karena selama pandemi ini pelayanan yang ada di perpustakaan ditiadakan sementara hingga waktu yang belum ditentukan.

Tantangan yang sedang dihadapi oleh perpustakaan Universitas Padjadjaran selama pandemi sangat bermacam-macam diantaranya dibagian layanannya, yaitu perpustakaan tidak bisa melayani pengunjung secara langsung. Dilihat dari pengunjungnya, yaitu masih belum diperbolehkan untuk menggunakan layanan di perpustakaan, maka aktifitas dan kegiatan dapat dikatakan tidak ada secara fisik. Dilihat dari koleksinya, koleksi buku yang dimiliki perpustakaan pusat Universitas Padjadjaran 99\% berbentuk fisik, sedangkan yang berbentuk e-book masih sangat terbatas serta tidak ada yang berbahasa Indonesia. Dilihat dari sistem kerjanya, pegawai atau staf dibagi dalam sistem shift, yaitu pegawai bekerja 2 hari dalam seminggu dengan pembagian hari yaitu, pada hari Senin-Rabu, dan hari Selasa-Kamis, sedangkan hari Jum'at bekerja dari rumah. Segala sesuatu dan semua kegiatan seperti rapat atau penyelesaian pekerjaan dilakukan secara daring melalui zoom atau lainnya.
Jenis layanan yang disediakan oleh perpustakaan Universitas Padjadjaran selama pandemi ada 3 macam, yaitu: (1) layanan administratif, berupa surat-surat, (2) layanan penelusuran informasi, tersedia Online Public Access Catalogue, juga pustakawan subject specialist untuk membantu pengguna dalam menelusur informasi, rujukan, dan lainnya, (3) pengembalian buku yang dilakukan dengan cara mengirimkannya melalui jasa kurir ataupaket, dan selama perpustakaan pusat tutup tidak dikenakan sanksi atau denda keterlambatan pengembalian buku. Inovasi yang digunakan perpustakaan Universitas Padjadjaran selamapandemi Covid-19 supaya tetap dapat dimanfaatkan secara maksimal oleh pengguna adalah disediakannya fasilitas SSO (Single Sign On) dengan nama produk EZProxy yang memungkinkan pengguna untuk mengakses e-journal dan e-books yang dilanggan. Sebelum pandemi, akses e-journal dan e-book hanya dapat dilakukan dengan menggunakan https://kandaga.unpad.ac.id dan hanya bisa diakses dengan wifi Universitas Padjadjaran di lingkungan kampus, baik di Jatinangor ataupun di Bandung. Fasilitas kedua yang disediakan adalah memperkuat website https://library.unpad.ac.id dengan menyediakan sumber- sumber informasi yang dapat diakses pengguna yang memerlukan referensi dan informasi. Fasilitas ketiga, yaitu menyediakan gray literature dalam website https://repository.unpad.ac.id, mahasiswa juga dapat mencari bahan pustaka melalui website https://kandaga.unpad.ac.id. Perpustakaan Universitas Padjadjaran juga menyediakan artikelartikel yang dapat diakses pada website https://jurnal.unpad.ac.id. Selain itu perpustakaan Universitas Padjadjaran berusaha untuk mengembangkan media sosial untuk menyampaikan segala informasi terbaru.

Perpustakaan Universitas Padjadjaran juga memiliki koleksi digital seperti e-books, jurnal, direktori, dan lainnya yang dapat diakses melalui SSO EZProxy yang nantinya dihubungkan dengan PAUS Universitas Padjadjaran dengan website https://pintu.unpad.ac.id, e-books dan e-journal yang dapat diakses diantaranya adalah (1) Cambridge, e-books yang membahas multidisiplin, (2) Clinicalkey, e-journal dan e-books yang membahas ilmu kesehatan, (3) Ebsco 
(multidisiplin), (4) Emerald, yang membahas ilmu sosial, (5) Oxford (multidisiplin), (6) Sage Journal (multidisiplin), (7) Sage Research Methods (multidisiplin), Springer nature (multidisiplin), dan Westlaw yang membahas ilmu hukum. Saat terjadi pandemi Covid-19 ini perpustakaan Universitas Padjadjaran telah melakukan kerja sama dengan Perpustakaan Nasional, dan masih dalam progress dengan Dinas Perpustakaan dan Arsip Daerah (DISPUSIPDA) Jawa Barat. Namun, tanpa melakukan kerja sama dengan pihak Perpustakaan Nasional, Perpustakaan dan Arsip Daerah, serta Perpustakaan Kota Bandung, sivitas akademika Universitas Padjadjaran sudah dapat memanfaatkan koleksi e-resources dengan mendaftarkan terlebih dahulu menjadi anggota secara gratis, dan masih banyak lagi informasi untuk dapat mengakses e-resources lainnya. Adanya pandemi ini menjadikan hubungan mahasiswa dan pihak perpustakaan menjadi sangat terbatas sehingga perpustakaan Universitas Padjadjaran melakukan segala cara supaya pengguna perpustakaan masih dapat mengakses informasi melalui website yang ada di Universitas Padjadjaran. Pusat Pengelolaan Pengetahuan (PPP) dan Perpustakaan Pusat melakukan literasi informasi serta menyebarkan informasi melalui sosial media seperti di Instagram Perpustakaan, serta Universitas Padjadjaran menyelenggarakan berbagai macam webinar sosialisasi e-resources yang dilakukan secara daring atau online. Untuk mengetahui informasi lebih lanjut, pengguna dapat menghubungi Perpustakaan Pusat Universitas Padjadjaran melalui e-mail Universitas Padjadjaran yaitu perpustakaan@unpad.ac.id/ pustakawan@unpad.ac.id/

pusat.pengetahuan@unpad.ac.id serta bisa juga melalui Instagram Perpustakaan Universitas Padjadjaran yaitu: @libunpad.

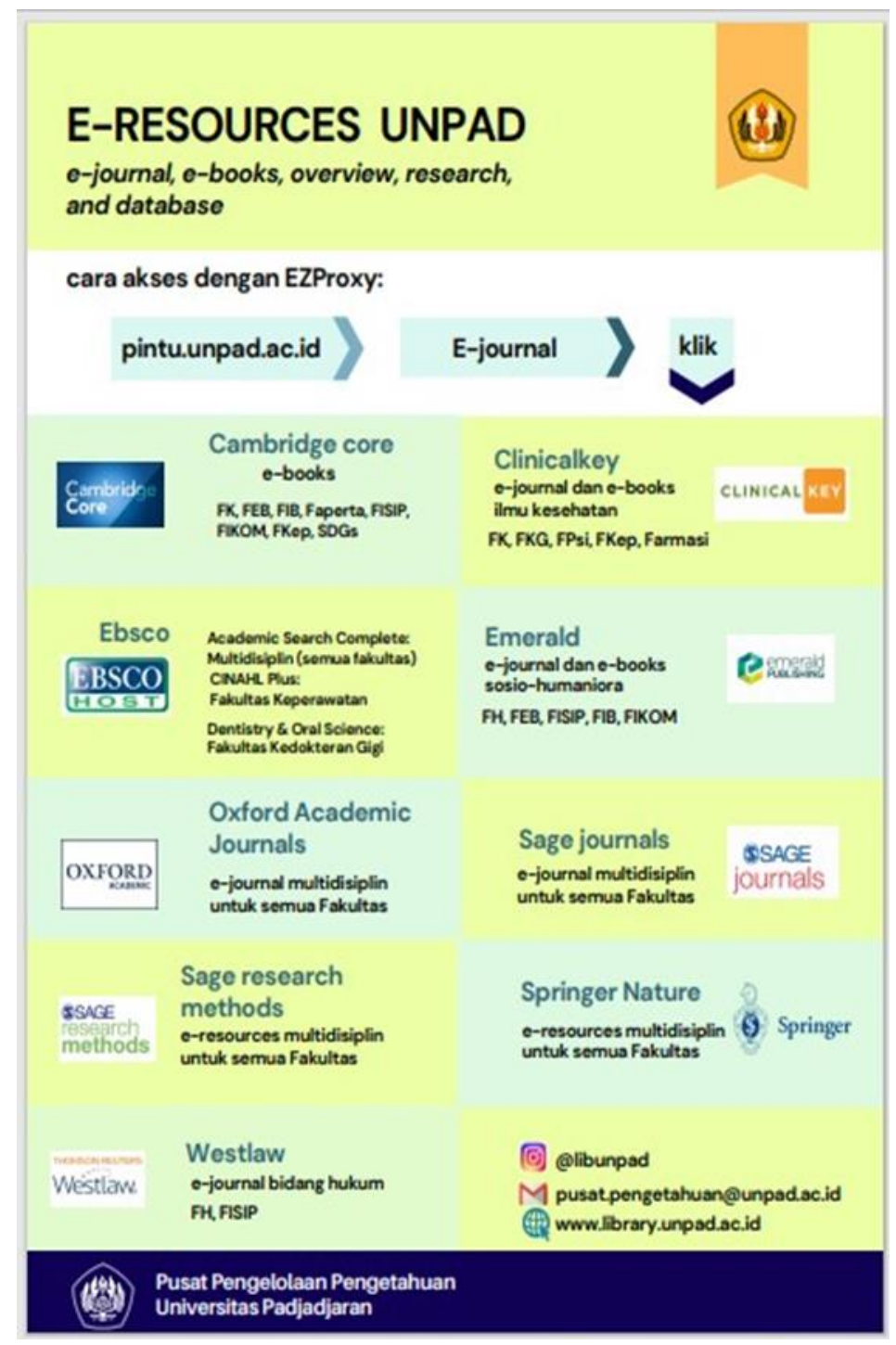

Gambar 1. Poster Tata Cara Mengakses EResources Universitas Padjadjaran

\section{KESIMPULAN}

Berdasarkan hasil penelitian dapat disimpulkan bahwa jenis layanan yang disediakan oleh perpustakaan Universitas Padjadjaran selama pandemi ada 3 macam, yaitu: (1) layanan administratif, berupa surat-surat, (2) layanan penelusuran informasi, tersedia Online Public Access Catalogue, juga pustakawan subject specialist untuk membantu pengguna dalam menelusur informasi, rujukan, dan lainnya, (3) pengembalian buku yang dilakukan dengan cara mengirimkannya melalui jasa kurir ataupaket, dan selama perpustakaan pusat tutup tidak dikenakan sanksi atau denda keterlambatan pengembalian buku. Inovasi yang digunakan perpustakaan Universitas Padjadjaran selamapandemi Covid-19 
supaya tetap dapat dimanfaatkan secara maksimal oleh pengguna adalah disediakannya fasilitas SSO (Single Sign On) dengan nama produk EZProxy yang memungkinkan pengguna untuk mengakses e-journal dan e-books yang dilanggan.

Layanan tersebut diberikan dengan tujuan dapat menjangkau segala kebutuhan pemustaka selama pandemi dan mendukung proses belajar mengajar dapat berjalan dengan baik dan optimal.

\section{DAFTAR PUSTAKA}

Creswell, J. W. (2012). Research Design: Pendekatan Kualitatif, Kuantitatif, dan Mixed. Pustaka Belajar.

Daryono. (2018). Membangun komunikasi efektif dalam pelayanan perpustakaan. https://ejournal.perpusnas.go.id/mp/article/d ownload/274/293

Depdiknas. (1994). Buku Pedoman: Perpustakaan Perguruan Tinggi. Direktorat Jenderal Pendidikan Tinggi Depdiknas.

Haryanto, H. (2019). Optimalisasi Layanan Perpustakaan Perguruan Tinggi Melalui Pemanfaatan Social Media Networking Sebagai Media Komunikasi Antara Perpustakaan Dan Pemustaka. Jurnal Pustaka IImiah,1(1),77. https://doi.org/10.20961/jpi. v1i1.33090

IFLA. (2018). IFLA/UNESCO Manifesto for Digital Libraries. The International Federation of Library Associations and Institution. https://www.ifla.org/publications/iflaunescomanifesto-for-digital-libraries

IFLA. (2020). COVID-19 and the Global Library Field. Den Haag: IFLA (The International Federation of Library Associations and Institutions). https://www.ifla.org/covid-19-and-libraries Istiana, P. (2014). Layanan Perpustakaan. 143.

K.E, P. (1998). Pendekatan Kualitatif Dalam penelitian Psikologi. Lembaga Pengembangan Sarana Pengukuran dan Pendidikan Psikologi (LPSP3) Fakultas Psikologi Universitas Indonesia.

Pendit, P. L. (2008). Perpustakaan Digital Perguruan Tinggi : Tantangan Peningkatan Kualitas Jasa. http://eprints.undip.ac.id/5367/2/makalah _pak_putu.pdf
PERPUS UNUSA. (2016). Tujuan dan Fungsi Perpustakaan Perguruan Tinggi. https://library.unusa.ac.id/2016/10/20/tujuan -dan-fungsi-perpustakaan-perguruan- tinggi/ S, N. (1987). Pengelolaan Perpustakaan.

Suharso, P. (2019). Pemanfaatan Drone Emprit dalam Melihat Trend Perkembangan Bacaan Digital melalui Akun Twitter. Anuva, 3(4), 333346. http://ejournal.undip.ac.id/index.php/anuva\% OAPemanfaatan

Sulistyo-Basuki. (1993). Perpustakaan Perguruan Tinggi. Gramedia. 